\title{
THE INTERNATIONAL ASSOCIATION FOR MILITARY GEOSCIENCES: A HISTORY TO 2017
}

\author{
Edward PF Rose \\ Honorary Research Fellow in Earth Sciences, \\ Royal Holloway, University of London
}

\begin{abstract}
The International Association for Military Geosciences (IAMG) was founded in 2013 at Aviemore in Scotland, during the $10^{\text {th }}$ International Conference on Military Geosciences. The conference series had begun in 1994 in the United States, with subsequent almost biennial meetings alternating between Europe and North America. Initially geological in their focus, however the meeting themes broadened over the years to embrace military aspects of both geology and geography, and subsequently geosciences as a whole. Numbering was introduced (and applied retrospectively) in 2005, and the series title stabilised in 2009. The IAMG foundation reflected a developing international interest in military geosciences, evidenced by a significant number of books and journal articles as well as ancillary conferences focused on this discipline in recent years.
\end{abstract}

\section{Introduction}

The International Association for Military Geosciences (IAMG) was founded in 2013 during the $10^{\text {th }}$ International Conference on Military Geosciences (ICMG), held at Aviemore in Scotland. The ICMG series had been pioneered by geologists: a one-day symposium in the United States in 1994, followed by another in England in 1996 and a half-day symposium in Canada in 1998. The scope was then extended to include both geology and geography and the meeting length extended to a conference of more than one day: in England in 2000, the United States in 2003, England again in 2005 and Canada in 2007. The word 'international' was added to conference names from 2003, and the series numbered sequentially (and retrospectively) from 2005. The scope later became 'military geosciences' as conference length became five days: in Austria in 2009, the United States in 2011, Scotland in 2013, and the United States again in 2015. The pattern established over the previous 20 years was thus of a near-biennial series of conferences convened alternately in North America and Western Europe, and by either academic or army/navy specialist initiative. At most conferences, a few scheduled talks had to be cancelled due to last minute absence of speakers, but each ICMG typically generated a hardback book of papers selected 
from those actually presented. In 2013, the IAMG was created on this firm foundation. In 2017, under its auspices, an ICMG was convened in Stellenbosch by the South African Military Academy, - the first time in Africa.

\section{Geological origins}
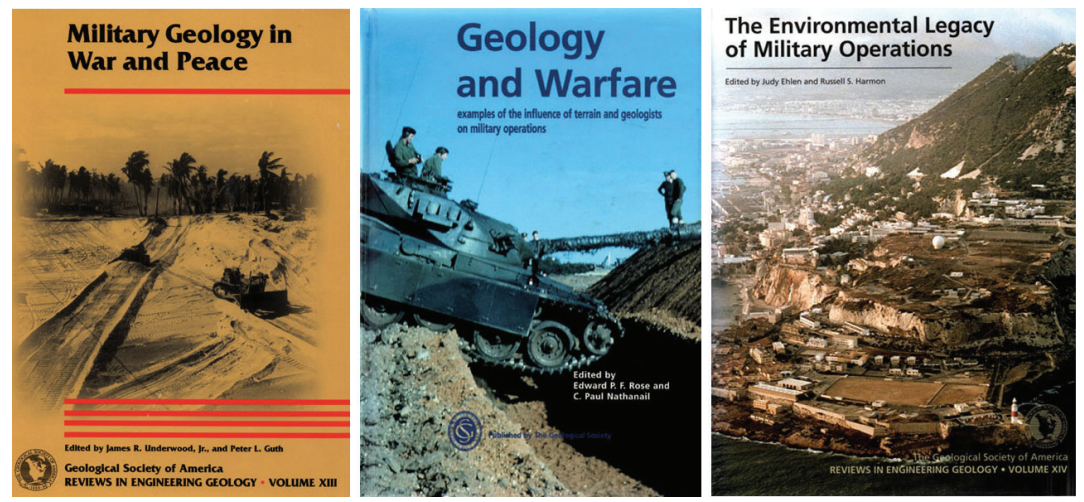

Figure 1: Detail from front covers of (a) first, (b) second and (c) third ICMG volumes.

The first 'ICMG', as the series was to become known, was a one-day symposium sponsored by the Engineering Geology Division of the Geological Society of America on the theme "Military Geology in War and Peace". It was convened by Professors Jim Underwood (of Kansas State University) and Peter Guth (of the US Naval Academy) during the 1994 annual meeting of the Society, held that year at Seattle, Washington, on the north-west coast of the United States. ${ }^{1}$ The meeting as a whole comprised 197 technical sessions, of which number 102 on the morning of Wednesday 26 October contained 15 short presentations on military geology, and number 127 in the afternoon a further 14. Three authors spoke twice, so the symposium featured 26 presenters. Of these, three came from the United Kingdom; all other speakers were from the United States. ${ }^{2}$

The ICMG series was thus incipiently 'international'. The Geological Society of America is the world's largest geological society, and its annual meetings attract some 5000 registrants, but no register was kept of those who attended the 'military geology' sessions. Memories are of a meeting hall able to seat an audience of up to about 200 people, with the majority of seats occupied for much of the day and at times with standing room only. ${ }^{3}$ The large number in the audience and hence the obvious appeal of the subject came as a surprise to the conveners, who hastily arranged a breakfast meeting the next day to discuss how best to respond to this interest, before participants dispersed from Seattle. During discussion, there was popular demand (amongst the few dozen people present) for another meeting, and for this to be in England to be followed by a field trip to Second World War battlefield sites in Normandy. A 
post-conference book of 25 papers ( 21 by American, four by British first authors) comprising 245 pages was subsequently published (Figure 1a). ${ }^{4}$

The second ICMG was another one-day symposium, but in the United Kingdom and sponsored by the Engineering Group of the Geological Society of London, on the theme "Best Use of Ground: Lessons from Military Geology". It was convened by Drs Paul Nathanail (then of Nottingham Trent University) and Ted Rose (of Royal Holloway in the University of London) during the Society's Applied Geoscience conference held between 15 and 18 April 1996 at the University of Warwick, some $130 \mathrm{~km}$ north-west of London. ${ }^{5}$ The overall conference was an innovation for the Geological Society of London: its first attempt to generate a meeting series comparable with the annual meetings of the Geological Society of America. However, it was not successful: only one further such British conference was attempted before the initiative was abandoned. Based on the American model, it was thought that the conference and its symposium would attract many registrants from the United States. However, despite wide-ranging publicity, only one American contributed a paper to the military geology symposium. Sixteen other scheduled presentations came from British authors (one speaking three times and another twice), joined by Hermann Häusler from Austria and his co-author Dierk Willig from Germany. An international perspective was thus preserved and broadened. The overall meeting attracted registrants in hundreds rather than thousands, and the symposium audience was correspondingly small: about 25 people. Nevertheless, the presentations attracted media interest: three 'military geologist' contributors were amongst the few conference members interviewed for a news programme on the local radio, an event that proved to be unique in the ICMG conference series. The field trip to Normandy, organised at American request, transformed into a working group of seven people (one French, two German, and four British, led by Ted Rose with Emeritus Professor Claude Pareyn of the University of Caen), initiating the studies that ultimately generated an innovative 98-page military geology field guide. ${ }^{6}$ A post-conference book of 15 papers comprising 498 pages was also duly published, 11 chapters with British first authors, two Austrian, one American and one French, its title chosen to indicate the chapters actually contributed rather than the intended conference theme (Figure 1b). ${ }^{7}$

The third ICMG was convened once more during an annual meeting of the Geological Society of America, and under the auspices of the Society's Engineering Geology Division: a half-day symposium held in Toronto, Canada, during the morning of 26 October 1998, on the theme "Military Applications of Engineering Geology". Convened by Drs Russ Harmon (of the US Army Research Office) and Judy Ehlen (of the US Army Engineer Research and Development Center), this attracted 12 speakers, three of them British: two from the first and second ICMGs, the other from the second. All other presenters were based in the United States. Both the meeting and the symposium were well attended, but the audience as well as the list of presenters was smaller in number than at the first ICMG. Possibly 'military geology' was no longer a novelty that attracted non-specialists to its audience, but it was also evident that geologists formerly associated with military work by the US Geological Survey and who provided the core of interest at the first ICMG, were unwilling or unable to 
travel outside the United States. A post-conference book of 14 chapters comprising 228 pages was generated by incorporating a few appropriate papers given at other sessions during the meeting, with 11 first authors who were American and three British (Figure 1c). ${ }^{9}$ As with the previous ICMG, the book title was changed from that of the conference to indicate a theme linking the papers actually published.

\section{Geology and geography}
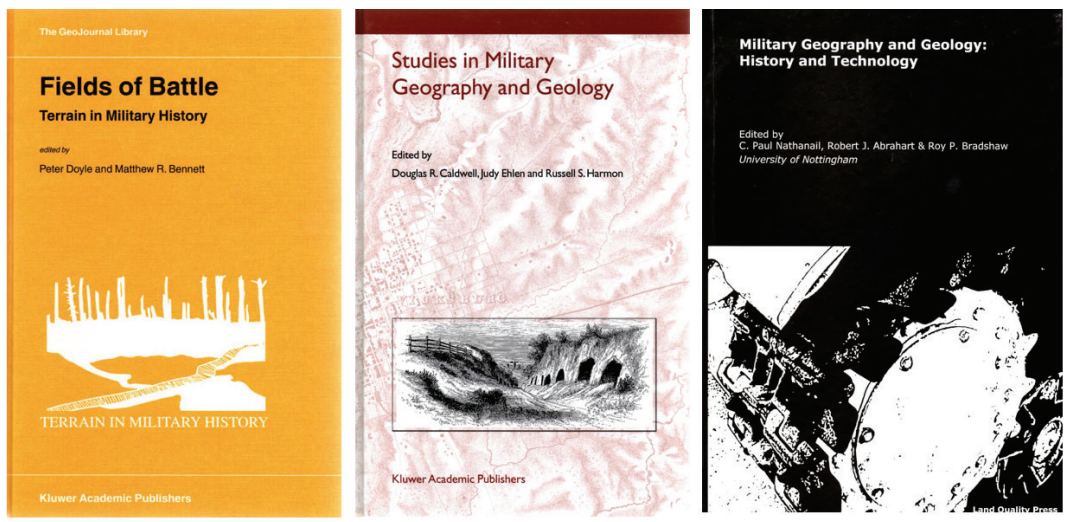

Figure 2. Front covers of (a) fourth, (b) fifth and (c) sixth ICMG volumes.

The fourth ICMG was quite different, in not being confined to geologists or to a single day. Stimulated by participation in the second ICMG (and subsequent grant-funded research), Drs Peter Doyle and Matthew Bennett of the University of Greenwich convened a conference in England on 5-6 January 2000 resident at the University's campus at Chatham, some $50 \mathrm{~km}$ east of London. Themed "Terrain in Military History", this was held in association with the Royal Engineers Museum (colocated with the Royal School of Military Engineering in Chatham), together with the Imperial War Museum in London (the British national museum that records the war effort and sacrifice involving British and Commonwealth forces since the beginning of the First World War, in 1914). The conference brought together geologists with geographers, historians, military enthusiasts and terrain analysts from military, academic and amateur backgrounds: 54 participants in total. Its aim was to explore "the application of modern tools of landscape visualisation to understanding historical battlefields". ${ }^{10}$ After a mid-morning welcome by the University's Chancellor, 16 presentations were scheduled for the first day (Wednesday 5 January) followed by a wine reception, and a further 17 for the second day, followed by a reception in the Royal Engineers Museum that marked the end of the conference as such. Friday began with a visit to the Imperial War Museum for those opting for post-conference events, and concluded with a group departing for a field trip by minibus. Led by Peter Doyle, this explored the geology of the Western Front battlefields of 1914-1918, in Belgium and northern France, until Sunday 9 January. A post-conference book comprising 387 pages contained 21 of the papers presented at the conference, 15 with first authors 
from the United Kingdom, four from the United States, and one each from France and Belgium (Figure 2a). ${ }^{11}$

The fifth ICMG was publicised as an "International Conference on Military Geology and Geography", in the hope that adding 'International' to the title would make it easier for academic staff to obtain grants for conference attendance. It was held in the eastern United States from 15-18 June 2003, hosted by the Department of Geography and Environmental Engineering at the US Military Academy, West Point, New York, under the guidance of a team led by Colonel (Col.) Gene Palka and Lieutenant Colonel (Lt Col.) Frank Galgano. A spectacular success, it attracted 94 contributors, including many officers from the Academy present in uniform: an indication that this ICMG had official military as well as academic support. A volume printed for the conference contained 61 abstracts for oral presentation and five for posters. Most first authors came from the United States, but two came from the United Kingdom (both veterans of several earlier ICMGs), two from Canada and one from India. Second authors present included at least one from Germany. To accommodate the abundance of papers submitted, after the plenary sessions that opened the first morning, subsequent papers were presented in two parallel sessions in adjacent rooms. The programme was punctuated with a river trip and a visit to historic fortifications, but there was no post-conference field trip. To restrict the post-conference book to an economic size, only one submission per author was allowed, and the papers were more strictly limited in word length and number of illustrations than permitted for previous ICMGs. From those submitted, 25 papers were selected (22 with first authors from the United States, two from Canada and one from the United Kingdom) to comprise a volume of 348 pages. This was published by Kluwer Academic Publishers, as for the fourth ICMG proceedings volume (Figure $2 \mathrm{~b}$ ). ${ }^{12}$

The sixth ICMG, styled the "Sixth International Conference on Military Geology and Geography", was hosted in central England by the School of Geography in the University of Nottingham from 19-22 June 2005. The conference was convened primarily by Dr Paul Nathanail, assisted by two other members of the School's academic staff: Drs Bob Abrahart and Roy Bradshaw. They formed a 'Scientific Committee' with three other members, who contributed experience from the organisation of previous ICMGs. Registration and welcome took place on Sunday 19 June. On Monday 20 June, two plenary keynote talks were followed by 12 presentations in parallel sessions, then by a field trip to view the ruins of the mediaeval Newark Castle and some battlefield sites of the $17^{\text {th }}$-century English Civil War. Tuesday 21 June opened with four plenary talks, including two keynotes, followed by five talks in parallel sessions, prior to field visits to the site of the late mediaeval Battle of Bosworth and to Fauld Crater. On 24 November 1944, this became the site of the largest explosion caused by conventional weapons in either world war, when 3500 tons of high explosives were accidentally detonated. Wednesday 22 June opened with two more keynote addresses, followed by eight talks in parallel session, prior to departure for a field trip to Normandy from 22-26 June led by Ted Rose and Paul Nathanail for 15 mostly North American participants. With the British Geological Survey (the world's oldest national geological survey in continuous existence) and the major Royal Engineers depot at Chilwell also based near Nottingham, the conference 
was well sited to attract non-resident participants: memories are of daily attendance in the range 40-50. Plans to publish a post-conference book faltered, but ultimately came to fruition with a book published locally comprising 336 pages and 24 chapters: 12 with first authors from the United States, nine from the United Kingdom, and three from Canada. However, collaborating authors from Estonia, France, New Zealand and South Africa indicate an even wider international participation (Figure 2c). ${ }^{13}$

The seventh ICMG, the "Seventh International Conference on Military Geology and Geography", was organised in Canada primarily by Dr Jean Martin (a veteran presenter and author of the fifth ICMG) from the Directorate of History and Heritage at the Canadian National Defence Headquarters in Ottawa but hosted at the Université Laval, in Quebec City, from 18-21 June 2007. After two welcoming talks on Monday 18 June, nine talks in sequence were followed by an afternoon visit to Quebec City and its Citadel. On 19 June, 12 talks were followed by an afternoon's field trip to geological features in the Quebec area, and a cruise on the St Lawrence River. On 20 June, 13 scheduled talks were followed by a panel discussion on the evolution of teaching military geography, before a third local excursion, this time to the Canadian Forces base nearby at Valcartier. On 21 June, 13 talks were scheduled before a small group departed for the post-conference field trip: visiting historic sites from the St Lawrence River to the Great Lakes. Presentations for which abstracts were printed comprised 28 with first authors from the United States, six from the United Kingdom, four from Canada, two from Austria, one each from France, Pakistan and South Africa. Daily attendance appeared to be similar to that in Nottingham: over 60 participants were formally registered and many more attended on a casual basis, requiring two buses for the local excursions. Overall, again a very successful, informative and enjoyable conference but, sadly, initial plans to publish the papers that had been submitted for the expected post-conference book never materialised.

\section{Geosciences}
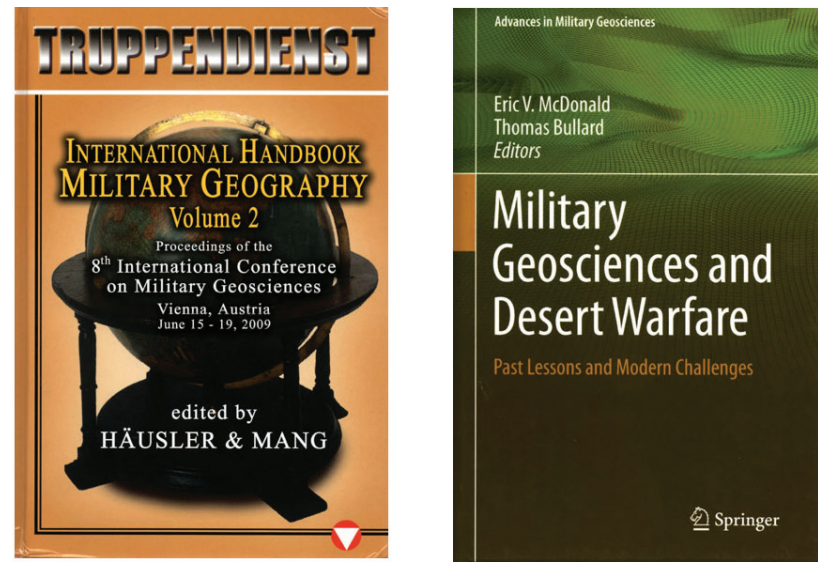

Figure 3. Front covers of (a) eighth and (b) ninth ICMG volumes 
The eighth ICMG was held, under that title, at the Austrian National Defence Academy, in Vienna, from 15-19 June 2009, and was convened by the Institute for Military Geography of the Austrian Armed Forces (led by Brigadier Reinhard Mang) and the University of Vienna Department of Environmental Geosciences (represented by Professor Hermann Häusler). ${ }^{14}$ This conference was the most ambitious so far. Its programme extended over five days: four days of lectures plus a couple of half-day excursions, punctuated by a spectacular whole-day excursion in the middle. Like the fifth and seventh ICMGs, it was resourced by a large team. In this case, the team comprised 26 people, mostly drawn from the Austrian Institute for Military Geography but a few also from the universities of Vienna and Salzburg and the Geological Survey of Austria: five to staff the organising committee, four the daily information desk, seven the excursions, two the poster sessions, six to provide technical and publication support, and two to function backstage.

Many of these contributed oral and/or poster sessions during the conference, which attracted 57 additional registrants, most (as typically) from the host nation (21 from Austria); many (17), also typically, from the United States; ten (an atypically large number) from Germany; three from the United Kingdom; and one each from Belgium, Canada, Croatia, France, South Africa and Syria. First authors from the United States (17), Austria (11), Germany (seven), the United Kingdom (three), Canada (two) and France (two) generated in total 42 oral presentations. First authors from Austria (ten), the United States (four), and Croatia, France, South Africa and the United Kingdom (one each) generated 18 poster presentations. For oral and poster presentations together, the United States and Austria thus led with a total of 21 each. However, by adding the seven German presentations to the 21 from Austria, it is clear that the conference provided a uniquely significant insight into past and present terrain expertise generated by armed forces using the German language - presented in excellent English. Significantly, groups of uniformed officers from the German and Austrian armies were led throughout the conference by officers of one-star (brigadier) rank. The programme was structured to provide a full day of presentations on the opening Monday and on Thursday, starting at 08:00, thus an hour earlier than some ICMGs. Tuesday and Friday had similarly early starts, but concluded with lunch, followed by a half-day guided excursion: on one day to see some of the historical sites of Vienna, including the Globe Museum with its unique display indicating developments in understanding of global geography through time; on the other day, to visit the Museum of Military History, whose extensive displays relating to the 1914-1918 and earlier wars were also of very significant interest. Wednesday was the longest day, but was devoted entirely to a choice of field excursions into the Alps. Some participants chose the excursion by coach and road: to the Semmerling area, to examine sites of confrontation between German and Soviet forces in the Second World War - and to the location on the Austria-Hungary border where the first government-approved breach to the Iron Curtain took place, in 1989. Most (about 40) chose the airborne alternative:

- flights by small aircraft and/or Blackhawk helicopter across much of southern Austria to demonstrate the main geological zones of this part of the Alps; 
- a visit to a First World War museum and cemetery near the Austrian-Italian border; and

- a long flight east along the border to view former front-line positions from the air, before continuing across the southern Eastern Alps back to the airfield near Vienna.

With such outstanding trips contained within the conference itself, it is perhaps not surprising that the post-conference excursion, to the historic city of Salzburg also prepared with great care - attracted only two participants additional to the leader. Several substantial publications were distributed free to participants at the beginning of the conference, some compiled especially for the conference. ${ }^{15}$ Moreover, a postconference book was published with impressive speed, comprising 537 pages and containing the largest number of papers (44) for any ICMG volume so far, 18 with first authors from Austria, nine from the United States, six from Germany, four from the United Kingdom, three from France, two from Canada, and one each from Croatia and South Africa (Figure 3a). ${ }^{16}$

The ninth ICMG, under that name, was convened in the western United States at Las Vegas from 20-24 June 2011, closely similar therefore in its date and duration to the previous ICMG. It convened under the auspices of the Desert Research Institute, the environmental research arm of the Nevada System of Higher Education. Its conveners were Drs Eric McDonald and Tom Bullard from the Institute, supported by an 'Organising Committee' comprising Gene Palka, Peter Guth, Steve Henderson plus Wendell King, all six being veteran contributors to previous ICMGs, with 17 other people also acknowledged and thanked in an elegantly printed abstract booklet. Monday, 20 June began with two welcoming speeches, followed by 19 oral presentations, and ended with a reception, poster presentations, and an Atomic Testing Museum tour. Tuesday 21 June began with nine further oral presentations, followed by an afternoon field trip to the Las Vegas Army Airfield Aerial Gunnery Range Site. Wednesday 22 June was entirely filled by a field trip to the Nevada National Security Site (formerly known as the Nevada Test Site), providing an opportunity to review the history of atomic testing from 1952 to 1992. Thursday 23 June began with ten more oral presentations, followed by an afternoon field trip to the Hoover Dam and to Boulder City. Friday 24 June began with 13 oral presentations, and ended in the afternoon with departure for the post-conference field trip, to the Mojave Desert and San Diego - an excursion that was well attended. In total, the 51 printed abstracts for oral presentations comprised 41 with first authors from the United States, three from Israel, two from the United Kingdom, one each from Canada, Croatia, India, Italy and South Africa. Twelve abstracts were printed for poster presentations: seven with first authors from the United States, three from Italy and two from South Africa. Peak daily attendance exceeded 50 people. Kluwer Academic Publishers who produced the postconference volumes for the fourth and fifth ICMGs had been taken over by the larger international company Springer, who duly published the volume for the ninth ICMG: a book of 375 pages comprising 22 chapters, 19 with first authors from the United States, one each from Israel, the United Kingdom and South Africa (Figure 3b). ${ }^{17}$ The 
publication of this book initiated a new interdisciplinary series by Springer, entitled "Advances in Military Geosciences".

\section{The International Association}

The tenth ICMG was held from 16-21 June 2011, its timing consistent with the two previous ICMGs. It was convened primarily by Hugh Hamilton, a senior lecturer in photography at Nottingham Trent University in central England and a veteran presenter of the seventh, eighth and ninth ICMGs. A passionate Scotsman, Hugh chose a conference centre at Aviemore in the Highlands of Scotland as the venue, expecting that the region's spectacular scenery, complex geology and unique military history would prove attractive to participants drawn from an international field. The Highland Council, the largest local government in the United Kingdom, funded a welcome reception on Sunday 16 June. Monday 17 June was filled by 12 oral presentations, followed by a meeting expected to discuss potential venues for future ICMGs. Tuesday 18 June began with five oral presentations, followed by an afternoon field trip. Led by battlefield archaeologist, Dr Tony Pollard from Glasgow University, half the group went to the site of the Battle of Culloden. In 1746, the last land battle within the United Kingdom was fought here (the final confrontation between 'Jacobite' insurgents attempting to restore the deposed Roman Catholic King James and forces loyal to the government of the day and its Protestant King George). Led by military veteran Bryden Ritchie of Edinburgh Napier University, the other half fired a variety of weapons dating from 1790 to 1939 at Cawdor Rifle Range nearby, the two groups changing over halfway through the afternoon. Wednesday 19 June followed the pattern of the two previous ICMGs with a full day in the field, on this occasion to explore sites of historical and geomorphological significance. Thursday 20 June began with a morning visit to Fort George (Figure 4a). This was constructed to help pacify the Scottish Highlands in the wake of the Jacobite Rebellion of 1745-1746, and is the mightiest artillery fortification in Britain. The afternoon contained eight oral presentations and an evening conference dinner at which Dr Mark Bulmer (then based at the University of Maryland, USA) delivered a keynote address. Friday 21 June contained eight further oral presentations, before the conference ended in time for participants to begin their long journeys out of Aviemore. Oral presentations therefore came to a total of 33: 13 from the United Kingdom, nine from the United States, four from Italy, two from South Africa, one each from Canada, Finland, India, Israel and Spain. A moratorium on US government grants for conference attendance reduced the number of registrants expected from the United States, so total participation involved only about 40 people. Plans for a 'proceedings' volume lapsed over the following years. 



Figure 4. Views of (a) Fort George, north-east Scotland, from the air ${ }^{18}$, and (b) the US Naval Academy campus, north-east United States. ${ }^{19}$

It was during the discussion meeting on the evening of Monday 17 June that a proposal to found the IAMG was put forward by Hugh Hamilton, and a draft constitution for it (compiled by Jean Martin of Canada) was tabled. Both the proposal and the constitution met with general agreement. A 'Co-ordinating Committee' was duly elected together with an honorary president, but not a secretary to deal subsequently with applications for IAMG membership or with correspondence. Consequently, the IAMG did little in the next two years except to support plans for the next ICMG.

The eleventh ICMG was convened from 14-19 June 2015 (consistent with the length and timing of the three previous ICMGs), on the east coast of the United States, at the US Naval Academy, Annapolis, Maryland. The 'Organizing Committee' comprised Eric McDonald and Barbara Jackson (research professor and programme specialist respectively at the Desert Research Institute) bringing significant experience from the ninth ICMG, plus Peter Guth (Professor of Oceanography at the Academy, and co-convener of the first ICMG) and Lt Col. Chris Gellasch (a frequent contributor since the fifth ICMG) both from the United States, together with Dr Mark Bulmer and Major (Maj) Drew Craig (new British participants from the tenth ICMG). The conference, promoted as on "The future of military geosciences: scientific capabilities, global security, and sustainability", opened with registration and an evening reception on Sunday 14 June. Monday 15 June began with nine scheduled half-hour presentations, followed by demonstrations and dinner hosted by Mark Bulmer at his family's Roedown Farm research centre. Seven presentations were scheduled for Tuesday 16 June, followed by a visit to the Hermione (a square-rigged wooden sailing ship fortuitously visiting the harbour: an exact replica of the French Navy late $18^{\text {th }}$-century frigate associated with General Lafayette, the French aristocrat and military officer who fought with distinction in the American Revolutionary War). The day ended with a guided tour of the Academy (Figure 4b), and dinner in the Academy Club. Wednesday 17 June comprised the mid-conference field trip led by Bob Whisonant (of Radford University, Virginia) and Judy Ehlen (formerly of Radford University) to the Antietam National Battlefield, to demonstrate how geology had affected the outcome of a major battle in 1862, during the American Civil War. Key aspects were illustrated by a guidebook containing reprints of two of their published 
articles. ${ }^{20}$ Six presentations were scheduled for Thursday 18 June, followed by a tour of the late $18^{\text {th }}$-century Fort McHenry (well known for its successful defence of Baltimore Harbour from an attack by the British Royal Navy during the War of 1812) and a visit to the harbour itself. Friday 19 June brought the conference to a close, with five more presentations, a detailed proposal to host the twelfth ICMG in South Africa, and the annual general meeting (AGM) of the IAMG. In total, 27 presentations were scheduled but only 24 actually delivered, by 19 speakers: 12 from the United States, three from the United Kingdom, two from South Africa, one each from Croatia and Israel. Registrants numbered about 35, to whom abstracts were given as a stapled set of photocopies rather than a printed booklet. However, firm proposals were made for publication of a 'proceedings' volume, to be edited by Peter Guth, which also had to include some of the as yet unpublished papers presented at previous ICMGs, and that work is currently in progress.

The AGM, chaired by Ted Rose as president, approved minor changes to the constitution, elected a new 'Co-ordinating Committee', and established the post of IAMG secretary. Maj Drew Craig of the Royal Engineers (Volunteers) was elected to serve in this appointment, and kindly offered to initiate a newsletter series and a website. ${ }^{21}$ Hennie Smit and Jacques Bezuidenhout of the South African Military Academy (who had both contributed to the ninth, tenth and eleventh ICMGs) proposed that the twelfth ICMG be held in South Africa and this was formally approved, with acclamation.

\section{South Africa}

The twelfth ICMG was duly convened from 18-23 June 2017, at the Stellenbosch Institute for Advanced Study (STIAS) - a centre replacing the intended venue of a wine estate because of last-minute fire damage. It was convened by Commanders Jacques Bezuidenhout and Hennie Smit of the South African Navy, from the University's Faculty of Military Science (South African Military Academy), supported by an Organising Committee (Wayne Dalton, Andries Fokkens, Vusi Malaza, Babalwa Mtshawu, Marion Prins, Ali Sehone and Ian van der Waag) and by a Scientific Committee (Godwin Ayirebi and Mark Blaine). It began in the now time-honoured manner with a welcoming function and registration on the Sunday evening (18 June). Monday opened with a welcoming address from the Dean of the Faculty of Military Science, followed by the conference organisers, the IAMG President, and a keynote address from Professor Mike Meadows, Secretary-General and Treasurer of the International Geographical Union. Ten papers followed, on military environmental management and the influence of climate and terrain on military operations in Africa, before participants adjourned to a wine cellar for tasting and snacks. Tuesday was filled prior to the afternoon AGM of the IAMG by 13 papers on military geology, physical military geoscience, and historical military geoscience. Wednesday served to punctuate the presentations with a full day off campus: a tour of the Cape Peninsula, a visit to the $17^{\text {th }}$-century Castle of Good Hope in Cape Town, and time to explore the town and its V\&A Waterfront. On Thursday, the presentations resumed: eight of them, comprising an open session plus a session on military archaeology and heritage, prior to a conference dinner in the evening at which Professor Luke Sandham (Figure 
5b), President of the Society of South African Geographers, gave a keynote address. Friday morning included a further eight presentations, mostly on military mapping or featuring work by Stellenbosch students, before the conference ended with lunch. A printed book of abstracts (Figure 5a) was restored at this meeting: containing abstracts for two posters plus 38 papers, 17 papers with lead speakers from South Africa, five each from the United States and the United Kingdom, two each from Austria and Italy, one each from Canada, Croatia, France, Germany, Israel, Namibia and Portugal. Excellence of administration continued into the six-day post-conference field trip, for 20 participants, to visit the region of KwaZulu-Natal to view sites of some of the pivotal battles fought on South African soil (Blood River, Isandlwana, Rorke's Drift and Spioenkop, together with the site of the armoured train ambush near Chieveley that led in 1899 to capture by Boer commandos of the future British prime minister Winston Churchill), as well as major features of its terrain and wildlife.

At the IAMG AGM held on the Tuesday -

- minor changes were agreed to the constitution;

- plans were approved to publish a theme set of conference papers in Scientia Militaria;

- a proposal by Aldino Bondesan (of the Department of Geosciences, University of Padua) to convene the 13 th ICMG in northern Italy was warmly welcomed and endorsed; and

- a new Council to support that initiative was elected.

Ted Rose retired as President on completion of his four-year term of office, and Commander Hennie Smit of the South African Military Academy was unanimously elected to fill the vacancy: testimony to the success of the South African ICMG already apparent as well as Smit's significant long-term contributions to the ICMG series.
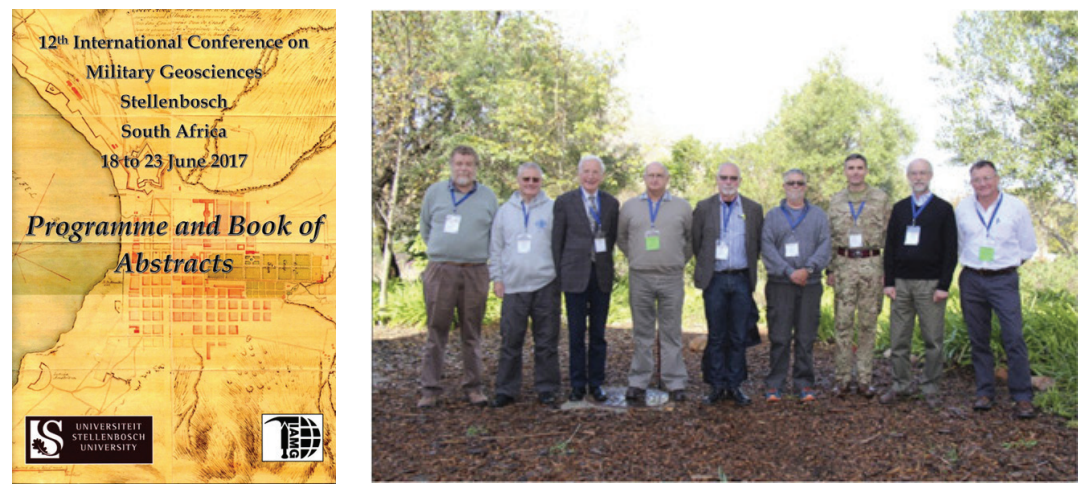

Figure 5. (a) Abstract book for $12^{\text {th }}$ ICMG, with IAMG logo, and (b) $12^{\text {th }}$ ICMG group photograph showing (left to right) keynote speaker Luke Sandham with conveners from the ICMG series: Hermann Häusler, Ted Rose, Hennie Smit, Jean Martin, Eric McDonald, Mark Bulmer, Peter Guth and Jacques Bezuidenhout (all cited in the text above). 


\section{Concluding remarks: the wider effect}

Over the last 20 years, the twelve ICMGs have significantly raised the profile of military geosciences as an academic discipline by acting as a catalyst for other conferences and books and for an influential number of papers published in respected peer-reviewed journals - as may for brevity be demonstrated from geology alone rather than extend this review to include geography also or geosciences as a whole.

Notably, the first eleven ICMGs have already generated eight books (Figures 1, 2 and 3), with another (following the eleventh ICMG) currently in preparation. There were no military geology books before the First World War and only three monographs in the English language prior to the Second World War, ${ }^{22}$ although several such books have been published in German..$^{23}$ The first three geology-based ICMG volumes therefore made a significant contribution to knowledge. Moreover, they stimulated more recent geology-based conferences in the United States and the United Kingdom, not as IAMG events but initiated by long-term ICMG contributors who are current IAMG members. Thus in the United States, papers on military geology have featured at several sectional meetings of the Geological Society of America. Judy Ehlen published a battlefield guide in 2004 to accompany one such meeting, in Virginia. ${ }^{24}$ More recently, Chris Gellasch and Russ Harmon convened a half-day session on "Military Geology in the $21^{\text {st }}$ Century" at the 2010 annual meeting, held at Denver, Colorado. Together with other papers, several inspired by an earlier workshop convened at the Desert Studies Centre in California by Eric McDonald, the presentations generated a 215-page book of 18 chapters, all but one contributed by American first authors. ${ }^{25}$ Another recent American book, ${ }^{26}$ written by ICMG contributor Bob Whisonant, was not generated by a symposium. In the United Kingdom, Ted Rose (with John Mather) convened a one-day symposium in London in November 2009 under Geological Society of London auspices. Themed "Military Aspects of Hydrogeology: Past and Present", this generated a 374-page book of 20 chapters, 12 by British first authors, five American and three German. ${ }^{27}$ As a sequel, Ted Rose and Judy Ehlen (with Ursula Lawrence) convened a one-day symposium in London in November 2016, again under Geological Society of London auspices, on "Military Aspects of Engineering Geology: Past and Present". Its post-conference book (containing papers by British, American, German and Austrian first authors) began publication online in 2018 (for publication in hardback when the book is complete), to help mark the centenary of the end of the hostilities of the First World War. $^{28}$

A military geological field trip to Normandy after the second ICMG stimulated preparation and publication of a guidebook that facilitated a more extensive trip after the sixth ICMG. In 2014, the British guidebook was complemented by a more lavish guidebook published by the French equivalent to the British and US Geological Surveys, written by French authors but with a British IAMG collaborator. ${ }^{29}$ Three other books on military geology are scheduled for publication in France to help commemorate the end of the First World War, one again with British IAMG contributors. $^{30}$ 
Also with a First World War theme, Dierk Willig (a contributor to the second, fifth and eighth ICMGs) led a field trip in 2009 to the Ypres battlefield area of Belgium for military geologists of the German Army, to which two British participants and one Belgian were kindly invited. This generated a 225-page guidebook (mostly in German, but partly in English), extensively illustrated, which was published by the German Army in 2015. ${ }^{31}$ Its title page credits compilation to Dierk Willig plus four collaborators, two British, one Belgian and one German. Of these five, three are currently IAMG members.

The publication of these books is significant, but to scientists it is publication in highly cited peer-reviewed journals that is particularly important. In that context, it is worth noting that although articles on military geology continue to appear in professional publications such as the Royal Engineers Journal, ${ }^{32}$ in recent years, many have also been accepted for publication within mainstream geoscience journals with an international readership, for example the Proceedings of the Geologists' Association, ${ }^{33}$ the Quarterly Journal of Engineering Geology and Hydrogeology, ${ }^{34}$ and The Cartographic Journal. ${ }^{35}$ Indeed, the British Cartographic Society made its Henry Johns Award for the year 2005, an award for the best article published in The Cartographic Journal during the previous year, for a military geology article. ${ }^{36}$ Other articles have appeared by invitation in journals that are widely read if not peer reviewed. One example is Geoscientist: The Fellowship Magazine of the Geological Society of London, distributed monthly in hard copy to 12000 Fellows and accessible online to an even wider readership. ${ }^{37}$ Another example is Geology Today: published jointly by John Wiley \& Sons, the Geologists' Association and the Geological Society of London "to provide a balance of news and review articles of topics of current interest in the earth sciences, written in an accessible way by experts in the field" and edited by IAMG member Peter Doyle. ${ }^{38}$

In 2014, the Geological Society of London, the world's oldest national geological society, awarded its Sue Tyler Friedman Medal "for excellence in research in the history of geology" for the first time "for distinguished work in the history of military geology". ${ }^{39}$ In September 2015, the History of Geosciences Section of the Italian Geological Society held a two-day conference at Trento in northern Italy to examine the role of geologists and cartographers on the Alpine fronts during the First World War, the most extreme combat conditions faced by Italians and their Austro-Hungarian opponents. ${ }^{40}$ This was followed by a two-day field trip. The conference stimulated a further meeting, for one day, in Rome in January 2016. Moreover, an Italian Society for Military Geography and Geology has developed in recent years and its activities now complement the aims of the IAMG. ${ }^{41}$ All of this bodes well for the $13^{\text {th }}$ ICMG, to be held at Padua in northern Italy in 2019. 


\section{Endnotes}

${ }^{1}$ See Geological Society of America. Abstracts with Programs 26/7. 1994.

${ }^{2}$ The three from the United Kingdom were all at that time Royal Engineer officers in the British reserve army as well as university-based geologists.

${ }^{3}$ Memories are those of the author, discussed with Judy Ehlen and the symposium convener Peter Guth.

${ }^{4}$ JR Underwood Jr \& PL Guth (eds). Military geology in war and peace: Reviews in Engineering Geology XIII. Boulder, CO: Geological Society of America, 1998.

${ }^{5}$ RSJ Sparks, WJ French \& RJ Howarth (organisers). Applied Geoscience 15-18 April 1996 abstracts. London: Geological Society, 1996.

${ }^{6}$ EPF Rose \& C Pareyn. Geology of the D-day landings in Normandy, 1944. Geologists' Association Guide no. 64. London: Geologists' Association, 2003.

${ }^{7}$ EPF Rose \& CP Nathanail (eds). Geology and warfare: Examples of the influence of terrain and geologists on military operations. London: Geological Society, 2000.

${ }^{8}$ See Geological Society of America. Abstracts with Programs 30/7. 1998.

${ }^{9} \mathrm{~J}$ Ehlen \& RS Harmon (eds). The environmental legacy of military operations. Reviews in Engineering Geology XIV. Boulder, CO: Geological Society of America, 2001.

${ }^{10}$ P Doyle \& MR Bennett (eds). Fields of battle: Terrain in military history. Dordrecht: Kluwer Academic, 2002. ix.

${ }^{11} \mathrm{P}$ Doyle \& MR Bennett op cit.

${ }^{12}$ DR Caldwell, J Ehlen \& RS Harmon (eds). Studies in military geography and geology. Dordrecht: Kluwer Academic, 2004.

${ }^{13}$ CP Nathanail, RJ Abrahart \& RP Bradshaw (eds). Military geography and geology: History and technology. Nottingham: Land Quality Press, 2008.

${ }^{14}$ Professor Häusler was at that time a colonel in the Austrian reserve army.

${ }^{15}$ For example: H Häusler. "Report on National and International Military GeoConferences held from 1994 to 2007". MILGEO: A Series of Publications on Military Geography, 30 E. Vienna: Austrian Ministry of Defence and Sports, 2009.

${ }^{16} \mathrm{H}$ Häusler \& R Mang (eds). International handbook military geography Vol. 2. Proceedings of the $8^{\text {th }}$ International Conference on Military Geosciences, Vienna, 15-19 June 2009. Vienna: Truppendienst, Ministry of Defence, 2011.

${ }^{17} \mathrm{EV}$ McDonald \& T Bullard (eds). Military geosciences and desert warfare: Past lessons and modern challenges. New York, NY: Springer Science + Business Media, 2016.

${ }^{18}$ Stephen Branley: from Wikimedia Commons, re-used under the Creative Commons Attribution-Share-Alike 2.0 license.

${ }^{19}$ From Wikimedia Commons; available for free use.

${ }^{20} \mathrm{~J}$ Ehlen \& RC Whisonant. "Military geology of Antietam battlefield, Maryland, USA: - Geology, terrain, and casualties”. Geology Today 24. 2008. 20-27; J Ehen \& RC Whisonant. "Casualties, geology and terrain in the American Civil War”. In Nathanail et al. op. cit., pp. 139-154. 
$21<$ militarygeoscience.org $>$

${ }^{22}$ HE Gregory (ed.) Military geology and topography. New Haven, CT: Yale University Press, 1918; AH Brooks. "The use of geology on the Western Front”. United States Geological Survey Professional Paper 128-D. 1920. 85-124; Anon. The work of the Royal Engineers in the European War, 191419: Geological work on the Western Front. Chatham: Institution of Royal Engineers, 1922.

${ }^{23} \mathrm{E}$ Wasmund. Wehrgeologie in ihrer Bedeutung für die Landesverteidigung. Berlin: Mittler, 1937; K von Bülow, W Kranz \& E Sonne. Wehrgeologie. Leipzig: Quelle \& Meyer, 1938; W Kranz. Technische Wehrgeologie: Wegweiser für Soldaten, Geologen, Techniker, Ärzte, Chemiker und andere Fachleute. Leipzig: Jänecke, 1938; C Mordziol. Einführung in die Wehrgeologie. Frankfurt am Main: Salle, 1938.

${ }^{24} \mathrm{~J}$ Ehlen. "Terrain and the Battle of Fredericksburg, December 13, 1862". In S Southworth \& W Burton (eds), Geology of the National Capital Region - Field trip guidebook. US Geological Survey Circular 1264. 2004. 247-261.

${ }^{25}$ RS Harmon, SE Baker \& EV McDonald (eds). Military geosciences in the twentyfirst century: Reviews in Engineering Geology XXII. Boulder, CO: Geological Society of America, 2014.

${ }^{26}$ RC Whisonant. Arming the confederacy: How Virginia's minerals forged the rebel war machine. New York, NY: Springer, 2015.

${ }^{27}$ EPF Rose \& JD Mather (eds). Military aspects of hydrogeology. London: Geological Society, 2012.

${ }^{28}$ EPF Rose, J Ehlen \& UL Lawrence (eds). Military aspects of geology: Fortification, excavation and terrain evaluation. London: Geological Society, in press.

${ }^{29}$ R Couëffé with N Charles, P Graviou, T Pay, EPF Rose \& B Vittecoq. Curiosités géologiques des plages du Débarquement en Normandie. Orléans: BRGM Éditions, 2014.

${ }^{30} \mathrm{~F}$ Bergerat, A Blieck, P le Vigouroux \& J-C Porchier (eds). La terre et le feu: Géologie et géologues sur le front occidental. Paris: Association des Géologues du Bassin de Paris, Comité Français pour l'Histoire de la Géologie \& Société Géologique du Nord, 2018.

${ }^{31}$ D Willig with EPF Rose, I Heyse, C Allersmeier \& P Doyle. Militärhistorischkriegsgeologischer Reiseführer zum Wytschaete-Bogen (Messines Ridge) bei Ypern (Belgien). Schriftenreihe Geoinformationsdienst der Bundeswehr Heft 4, 2015.

${ }^{32}$ Some 30 articles of military geology relevance between 1978 and 2017 by EPF Rose, MS Rosenbaum or RIL Dow.

${ }^{33}$ At least seven military geology articles since 1993, by EPF Rose, MS Rosenbaum or P Doyle.

${ }^{34}$ Eight military geology articles since 2005, by JC Clatworthy, CM Nelson, NS Robins, EPF Rose or MS Rosenbaum as sole or joint authors.

${ }^{35}$ Six military geology articles since 2004, by EPF Rose, JC Clatworthy, NS Robins or D Willig as sole or joint authors. 
${ }^{36}$ EPF Rose \& D Willig. "Specialist maps prepared by German military geologists for Operation Sealion: The invasion of England scheduled for September 1940". The Cartographic Journal 41/1. 2004. 13-35.

${ }^{37}$ Geoscientist contains only two feature articles per issue, 24 per year, so the four military geology articles in 2011-2013 (two by T Rose, one each by S Mathews and J Dixon) formed a relatively significant proportion of the major themes selected.

${ }^{38}$ Between 1992 and the present day, Geology Today has published several feature articles and news items that relate to military geology, usually but not exclusively with ICMG contributors EPF Rose, P Doyle or MS Rosenbaum as the leading author.

39 “Society Awards for 2014”. Journal of the Geological Society of London 171. 2014. 739-740. For citation and reply, see Geoscientist for November 2014; also Newsletter of the History of Geology Group of the Geological Society of London 51. June 2014. 17-23.

${ }^{40}$ News item by A Argentieri in Geology Today 31/3. 2015. 89.

${ }^{41}$ Extensive information is provided on the society's website: www.siggmi.it. 